Santosa, B., \& Kamin, Y. (2018). CBT in the workplace in Indonesian vocational high school. Journal of Vocational Education Studies, 1(2), 59-64. DOI: https://doi.org/10.12928/joves.v1i2.700.

\title{
CBT in the workplace in Indonesian vocational high school
}

\author{
Budi Santosa1, Yusri bin Kamin ${ }^{2}$ \\ ${ }^{1}$ Universitas Ahmad Dahlan, Jl. Pramuka 42, Sidikan, Yogyakarta, Indonesia \\ 2Universiti Teknologi Malaysia, Skudai, Johor, Malaysia \\ *Corresponding author, e-mail: budi.santosa@mpv.uad.ac.id
}

\begin{abstract}
This study aims to describe the competency-based training (CBT) model in the workplace in vocational high school (VHS) in Indonesia. Students of VHS conduct learning in school and at workplace/industry. A good CBT model will produce skilled vocational graduates, which will reduce unemployment. The method used in this study is research and development by Borg and Gall. Research steps include: preliminary study, development, and testing of students, teachers, and industry mentors totaling 79 people. The finding of this research is that the CBT model implemented in the workplace must meet the following steps: (1) the student must have basic skills as stated in the skill passport, (2) the students choose the location of the practice which already has the memorandum of understanding with the school, (3) VHS assigns students to perform industrial work practice according to their approval from industry, (4) competency based assessment can be done through real work, (5) industry supervisor industry as an external assessor to test students, and (6) competencies that have been mastered by students recorded in skills passport.
\end{abstract}

Keywords: Competency-based training, Industrial work practice, Vocational high school.

\begin{abstract}
Abstrak
Penelitian ini bertujuan untuk menggambarkan model pelatihan berbasis kompetensi (CBT) di tempat kerja di sekolah menengah kejuruan (SMK) di Indonesia. Siswa SMK melakukan pembelajaran di sekolah dan di tempat kerja/industri. Model CBT yang baik akan menghasilkan lulusan kejuruan yang terampil, yang akan mengurangi pengangguran. Metode yang digunakan dalam penelitian ini adalah penelitian dan pengembangan oleh Borg and Gall. Langkah-langkah penelitian meliputi: studi pendahuluan, pengembangan, dan pengujian siswa, guru, dan mentor industri yang berjumlah 79 orang. Temuan dari penelitian ini adalah bahwa model CBT yang diterapkan di tempat kerja harus memenuhi langkah-langkah berikut: (1) siswa harus memiliki keterampilan dasar sebagaimana dinyatakan dalam keterampilan paspor, (2) siswa memilih lokasi praktik yang sudah memiliki nota kesepahaman dengan sekolah, (3) SMK menugaskan siswa untuk melakukan praktik kerja industri sesuai atas persetujuan mereka dari industri, (4) penilaian berbasis kompetensi dapat dilakukan melalui pekerjaan nyata, (5) industri pengawas sebagai penilai eksternal untuk menguji siswa, dan (6) kompetensi yang telah dikuasai oleh siswa yang dicatat dalam keterampilan paspor.
\end{abstract}

Kata Kunci: Pelatihan berbasis kompetensi, Praktik kerja industri, Sekolah menengah kejuruan.

\section{INTRODUCTION}

The quality of workers in Indonesia is still not able to meet the needs and answer the challenges in the labor market. The business world complains about the low competence of workers in certain fields. As a result, employers must issue additional investments to equip workers with the skills and expertise required of a particular business sector. The vocational school curriculum refers to the principle of a competency-based training, which is intended to meet the needs of the workforce, but not yet fully met. One proof is that graduate vocational schools do not have adequate competence, many graduates of VHS are unemployed. BPS (2017) shows the unemployment rate of 128.06 million people and unemployed from VHS of 803.641 people $(11.41 \%)$.

VHS aims to prepare graduates to be able to enter the field work, both working in the business world and industry or create employment/entrepreneurship. The tight 
competition of job seekers and also the number of foreign workers due to a free market, the prospective workforce VHS graduates are required to have a reliable skill. Competencybased training/CBT in vocational schools is conducted in schools and in industry. Learning in schools has not been able to meet the skills required by the industry, due to the lack of teaching and practice tools and teaching skills that resulted from the rapid pace of technological development in the industry.

Dewey (1916) argues that a vocation means nothing to a person, because of the consequences they accomplish, and also useful to his associate. This opinion states that vocational education is nothing but the direction of human life activity as a meaningful contribution to a person because of the consequences of their work and also useful for the workplace. According to Prosser (1925), vocational education is a process of teaching and learning that aims to prepare students for employment. Further, Prosser states that (1) vocational education will be efficient in proportion as an environment in which students are trained in an environmental replica in which it will later work, (2) vocational training will be effective if the training is given the job in the same way, with the same operation, with the same tools, and with the same machine, as in the real field of work. Effective vocational schools as training institutions should be able to provide the same facilities as those in the world of work. Thus, students can learn to do the same jobs as those in the industry. Students should be trained in the skills required by the world of work. Thus, vocational education is an educational institution that has the goal of preparing students with the skills and knowledge to enter the workforce.

Efficiency and effectiveness in the vocational education should provide training to students with situations as they occur in the workplace. Particularly one of the goals of VHS is to equip learners with competencies in accordance with the chosen skill program. Since VHS graduates are prepared to enter the work field, then the more economically, the higher the quality of one's education will be more productive. Thus in addition to increasing national productivity will also increase the competitiveness of labor in global markets.

\section{RESEARCH METHOD}

This study aims to develop a model of competency-based training in VHS. This research method is research and development (R\&D) developed by Borg \& Gall (1996). R\&D research is a process used to develop and validate educational products. Respondents consisted of students, teachers, and mentors of industry work practices from four schools and four auto/industry workshops.

The components of the developed model consist of: (1) development of competency standards, (2) curriculum development, (3) development of learning, and (4) development of industrial work practices. The research and development procedure is carried out in three stages: (1) preliminary study, (2) model development, and (3) model test. This research and development step can be described as follows. The first step is a preliminary study which contains: (1) literature study on the aspects studied, whether from theory study, research result, or field study related to competency test, and (2) preparation of product competency test draft conducted based on literature studies and expert judgment through focus group discussions with academics and practitioners of educational institutions and industry/associations. The second step is product development consisting of: (1) a limited product trial conducted on two VHS, and (2) an extended product trial conducted on four VHS. The third step is a test consisting of final product testing and outcome socialization.

\section{RESULTS AND DISCUSSION}

The results of in-depth interviews with practitioners, academics, and industry were analyzed and guided in the discussion. CBT can improve productivity, increase access to

Santosa, B., \& Kamin, Y. (2018). CBT in the workplace in Indonesian vocational high school. Journal of Vocational Education Studies, 1(2), 59-64. DOI: https://doi.org/10.12928/joves.v1i2.700. 
employment opportunities and raise the standard of living. The discussion includes the aspects of the development of competency standards, curriculum development, development of learning in the school and industry in Indonesian VHS.

\section{Development of Competency Standards}

Norton \& Moser (2008) mentions that in the analysis of standard tasks begins from job needs analysis and ends with the development of a competency profile. Norton's opinion suggests that in the development of competency standards it is necessary to do job needs analysis, which is stated in Indonesian national competence standards/INCS, and developed into a standard of competence.

Another opinion expressed by Kelly (2000) states that in formulating basic standards in vocational education, basic concepts and operations and humanitarian, ethical and social aspects should be developed. Norton and Kelly's statement reinforces the need for an alliance between competency standard of graduates and INCS in developing competency standards in VHS.

Standards of competence must be tailored to the needs of the world of work and are based on benchmarks. Arguments supporting the above statement delivered by Lester (2017) and Reeves (2004) which states that an educational approach based on standards including: (1) the standards are fixed, the intention is that in a system based on the standard, students should be able to conduct a competency determined, (2) standards measure proficiency, ability to do a job/task being the size of the standard system, (3) the standards are challenging, standard system to challenge all students to master the knowledge and skills that have been determined/standardized, and (4) standards are simple, the standard system of educational outcomes is competent or incompetent that is easy to understand. VHS aims to prepare students to enter the work field and develop a professional attitude, develop themselves, and become a middle-level workforce to fill the needs of business and industry. Guided by the goals of education in the VHS, the students are learning competency standard VHS must be adapted to the competence and jobs in the industry.

\section{Curriculum Development}

The results of in-depth interviews indicate that education experts in the field of curriculum developers should be involved in curriculum development, in addition to business and industry elements. The opinion that supports educational experts in the field of curriculum developers involved in curriculum development is Norton \& Moser (2008). Norton stated that the personnel involved in curriculum development consists of: (1) administrators, are academics in the field of vocational education, (2) instructional staff, is the instructor fields of engineering, (3) support personnel, is the developer of curriculum/program, and (4) advisory personnel, is a committee of experts / professional associations. Norton suggests that members should be involved so that the curriculum can be developed effectively and efficiently is covering the elements of engineering education experts, curriculum developers, and practitioners.

The expert team's suggestion that in developing the curriculum, students' needs and social conditions need to be considered in meeting employment needs in line with Rauner (2009) opinion which states that in the development of a vocational education curriculum; the occupational form of work becomes the point of reference for the development of curricula. Rauner's opinion suggests that in developing a vocational education curriculum, job forms related to positions/tasks become a reference in the development of the curriculum. Other opinions that support students' needs and social conditions need to be considered by Scott (2004) and Buker-Straub (2017) suggesting that vocational education as an educational institution should broaden opportunities for students to learn or work as needed, development in both academic and practical contexts.

Santosa, B., \& Kamin, Y. (2018). CBT in the workplace in Indonesian vocational high school. Journal of Vocational Education Studies, 1(2), 59-64. DOI: https://doi.org/10.12928/joves.v1i2.700. 


\section{Development of Competence-Based Training}

The results of input from the expert team, which states that the module as a learning resource needs to be enriched with other learning resources to provide flexibility in enriching students in accordance with the opinion of Norton \& Moser (2008) which states that learning should be able to provide programs for individual development and process learning can take place in the workplace. Another opinion that supports the above statement is proposed by Clark \& Winch (2007) which states that the principles of vocational education emphasize the benefits of information technology as a source of learning. Technology changes will always be optimized in the vocational learning process. So the source of learning is always enriched with the development of technology. Learning in VHS was developed using modules as one of the learning media and enriched using information technology as another learning resource.

Thompson (1973) states that vocational education is built on the following principles: first, it must be in accordance with the purpose of development. This opinion indicates that vocational education should always follow the development of technology in realizing development goals. This cannot be avoided because technology is always evolving as the times change. Second, the labor market maintains a balance between the needs of employment and unemployment, and between employment and a skilled workforce. This suggests that vocational education as a provider of trained workers can contribute to balancing the need for trained workers with available jobs. The consequence of this argument is that a vocational school should be able to provide trained personnel according to the type of work required. This statement suggests that vocational education should cooperate with the world of work so that it can map the needs of the workforce and train vocational school students as a potential employee to become a skilled workforce. The Thomson opinion supports the expert judgment notes that the model needs to be developed towards learning and cooperative learning in accordance with the demands of the curriculum.

The results of expert judgment record stating that the valuation model should consider the assessment process in line with the opinion of Clark \& Winch (2007) that the principle of in-depth curriculum reflected in an assessment system that aims to record what has been achieved across the learning system. In curriculum planning, it also contains what and how the learning process should be carried out, but also contains what and how the assessment system should be done. Another opinion which states that the assessment requires a process proposed by Miller (2008) and Finch (1999). Assessment is a broader term compared to general tests and processes that include collecting, synthesizing, and interpreting informal data and formal data. VHS student ratings undertaken during student study at VHS is a form of process assessment.

Important characteristics of the competency-based educational model according to Gonczi (1998) include: (1) a documented list of competencies accompanied by specific standards and conditions for each competency; (2) at any time the student may be assessed for the achievement of his competence when ready, (3) the learning takes place in the format of the module relating to each competency, (4) the assessment is based on certain standards according to the required competence, (5) the competency test is based on the demonstrated skill, (6) the student can proceed to the unit subsequent competencies if learned competencies have been achieved, (7) student learning outcomes recorded and reported in the competence book. Gonczi reinforces that competency-based assessment should be supported by a record of competence has been achieved, in this case, recorded in the skills passport. Gonzi's opinion is in line with Achtenhagen \& Winther (2014) states that perspective of teaching/training and learning/working processes demands new approaches to research.

Santosa, B., \& Kamin, Y. (2018). CBT in the workplace in Indonesian vocational high school. Journal of Vocational Education Studies, 1(2), 59-64. DOI: https://doi.org/10.12928/joves.v1i2.700. 


\section{Development of Industrial Work Practices}

Results of interviews with expert judgment on the monitoring and evaluation of the implementation industrial work practice (IWP) must always be carried out so that the program can be run effectively supported by the opinion Streumer (2006) which states that the practice of industrial workplace (on the job training/OJT) requires arrangements: (1) their clear training objectives, (2) the need for OJT evaluation to determine the achievement of training objectives. Results of interviews with the expert judgment which states that the program working practices industry there should be standardization of competence along with their performance criteria imposed in the workshop where the students practice the industrial work was supported by the opinions of Streumer (2006) which states that learning in the workplace based on the design of training as detailed in the theory of instructional design. Training objectives are established based on workplace task analysis and learning materials developed in accordance with conditions in the work environment. Standardization of competence along with their performance criteria program students VHS industry work practices outlined in the skills passport.

Halliday-Wynes \& Misko (2012) in his research on the competency test in the workplace found that the assessor and trainer involved in the study agreed that the competency test approach is the thorough and complete way through the clustering method in the competency test. This approach also helps students to consider what is important in learning as key principles and concepts, the relationship between ideas and the relationship of new concepts with prior knowledge. In this study, the assessor and trainer also believe that it is a very important method for students to clearly understand the context of that training and competency testing is all in one place. Halliday's opinion is reinforced that when students carry out IWP competence test can be done. The findings of the assessors who are less familiar with this competency test system in accordance with the opinion of Haines, Dennick, \& Antonio (2013), so that the requirements to become assessor is must have been certified as assessors.

The objectives of dual system education (PSG) by MOEC (1999) are: (1) to improve the quality and relevance of vocational education through the participation of partner/industry, (2) to produce graduates with knowledge, skills and work ethics in accordance with job demands, (3) to produce graduates who have the knowledge, skills, and attitudes on which to base their own sustainable development, (4) recognize and reward work experience as part of the education process, and (5) improve the efficiency of vocational secondary education through the utilization of resources education in the world of work. Two last statement suggests that PSG in the form IWP program can be used to give recognition and appreciation of the work experience as part of the educational process and to improve the efficiency of vocational education.

\section{CONCLUSION}

Learning components that can support the implementation of the CBT in workplace model are: (1) teachers must have professional competence, (2) competency-based learning model implemented in school and at work / industry, (3) students are provided with soft skills, and (4) validated skill passport becomes a guide to achieve competence and at the same time become a proof of achievement of competence.

The steps to be taken by the students in carrying out industrial work practices are: (1) the student must have basic skills as stated in the skill passport, (2) the students choose the location of the practice which already has the Memorandum of Understanding/MoU with the school, (3) SMK assigns students to perform IWP according to their approval from industry, (4) competency based assessment can be done through real work, (5) industry supervisor as an external assessor to test students, and (6) competencies that have been mastered by students recorded in skills passport.

Santosa, B., \& Kamin, Y. (2018). CBT in the workplace in Indonesian vocational high school. Journal of Vocational Education Studies, 1(2), 59-64. DOI: https://doi.org/10.12928/joves.v1i2.700. 


\section{REFERENCES}

Achtenhagen, F., \& Winther, E. (2014). Workplace-based competence measurement: developing innovative assessment systems for tomorrow's VET programmes. Journal of Vocational Education \& Training, 66(3), 281-295.

Büker, G., \& Schell-Straub, S. (2017). Global how? - Linking practice to theory: A competency model for training global learning facilitators. International Journal of Development Education and Global Learning, 9(2), 3-15.

Gall, M. D., Borg, W. R., \& Gall, J. P. (1996). Educational research: An introduction. Harlow: Longman Publishing.

BPS. (2017). Keadaan Ketenagakerjaan Indonesia Agustus 2017. Jakarta: Indonesian Bureau of Statistics.

Clark, L., \& Winch, C. (2007). Vocational education, international approaches, developments and systems. Oxon: Routledge.

MOEC. (1999). Keputusan Menteri Pendidikan dan Kebudayaan Republik Indonesia nomor 323/U/1997 tentang penyelenggaraan Pendidikan Sistem Ganda pada Sekolah Menengah Kejuruan. Jakarta: Department of Education and Culture.

Dewey, J. (1916). Democracy and education. New York: Dover Publications, Inc.

Finch, C.R., \& Crunkilton, J.R. (1999). Curriculum development in vocational and technical education, planning, content, and implementation. Needham Heights: Allyn \& Bacon.

Gonczi, A. (1998). Developing a competent workforce: adult training strategies for vocational educators and trainers. Leadbrook: National Centre for Vocational Education Research Ltd.

Haines, C., Dennick, R., António, J. (2013). Developing a professional approach to workbased assessments in rheumatology. Best Practice \& Research Clinical Rheumatology, 27(2), 123-136.

Halliday-Wynes, S., \& Misko, J. (2012). Assessment issues in VET: minimizing the level of risk. Adelaide: National Centre for Vocational Education Research.

Kelly, M. G. (2000). National educational technology standards for students, connecting curriculum and technology. Washington DC: International Society for Technology in Education.

Lester, S. (2017). Reconciling activity-based descriptions of competence with professional work. Higher Education, Skills and Work-Based Learning, 7(4), 381-393.

Miller, P. W. (2008). Measurement and teaching. Munster: Patrick W Miller and Associates.

Norton, E. R., \& Moser, R. J. (2008). DACUM (Developing a curriculum) Handbook Third Edition. Columbus: Ohio State University.

Prosser, C. A., \& Allen, C. R. (1925). Vocational education in a democracy. New York: Century.

Rauner, F. (2009). TVET curriculum development and delivery. In R. Maclean, D. Wilson (Eds.). International handbook of education for the changing world of work, bridging academic and vocational learning. Heidelberg: Springer Science+Business Media.

Reeves, D. B. (2004). Making standards work: how to implement standard-based assessments in the classroom, school, and district (3th ed.). Englewood: Advanced Learning Press.

Scott, L. J., Sarkees, M., \& Wircenski. (2004). Overview of career and technical education (3 ${ }^{\text {rd }}$ ed.). Homewood: American Technical Publishers, Inc.

Streumer, J. N. (2006). The effectiveness of OJT in the context of HRD. Dordrecht: Springer.

Thompson, J. F. (1973). Foundations of vocational education, social and philosophical concepts. Englewood Cliffs: Prentice-Hall, Inc.

Santosa, B., \& Kamin, Y. (2018). CBT in the workplace in Indonesian vocational high school. Journal of Vocational Education Studies, 1(2), 59-64. DOI: https://doi.org/10.12928/joves.v1i2.700. 